\title{
America, a revolutionary prophecy ${ }^{1}$ \\ Zhan-Jun ZHANG
}

\author{
Beijing International Studies University, Beijing, China,100024
}

zhangzhanjun@bisu.edu.cn

Keywords: America, William Blake, revolution, prophecy

\begin{abstract}
This paper discusses why William Blake entitled his one of his most important poems--America a prophecy. The author analyzes the issue from different aspects: the life story of William Blake, the social background and the image of Orc.
\end{abstract}

\section{Introduction}

"America is one of Blake's early prophetic poems, and the first which he himself entitled $a$ prophecy", it's written in what Blake called the "long resounding line" of seven stresses which he adapted from the early English measures know as "fourteeners".

America is etched in the years 1791-1793, and it begins from the Boston Massacre of 1770, through the American Revolution and then it deals with the contagion of the revolutionary impulse among radical groups in England; it ends with a reference to the outbreak of the French Revolution and a prediction of the spreads of revolution through the Europe and all over the world.

In America, we can find the intense conflict between the main character---Orc and the evil images-Albion, Urizen. Here Blake offers us a complete process of Orc's success: be chained, get free, get ready for war, quarrels, Orc's new life explose enemy's evil deed, outbreak of the war, prediction of bright future, violent scene in battlefield, and the final success.

Though in America there are many veiled references to historical events of the time, Blake treats these facts freely. By using his rich imagination, he makes them embody the permanent from of all revolutions.

Obviously, Orc, in this poem, represents the spirits of revolution. The evil images in the poem are Albion, the embodiment of George III, the king of England, and all the reactionary rulers in the European continent. They attempt to extinguish the fire of revolution, and maintain the old corrupting ruling system.

\section{Blake, the author}

\section{Life story}

William Blake is born in 1757 as the second child in his family. His father is a London haberdasher and his mother is a pagan. His family is not rich, but the education is not bad: Blake studies what he likes in his home-reading and drawing. Then he enters a drawing school at the age of 10, where he shows his unusual talent and later studies for a time at the school of the Royal Academy of Arts . At 14, he apprentices for seven years to a well-known engraver. Thus engraver becomes his life-long occupation and affects him greatly.

Blake engraves for his poems: song of innocence and experience, but as a living method, he also uses the skill for other poets to get his bread: for Edward Young's poem which is published in 1797. Unfortunately, the economic depression makes him get little payment. When he engravers for Robert Blair's poems, the same thing happens again.

These experiences are not Blake's own humiliation, but the whole decade's: Millions of people have just the same bitter experience as Blake: the well-skilled watchmakers have to work in the factories, the weavers strike for a piece of bread, the owners of groceries are bankrupting and so on.

\footnotetext{
1 This paper is sponsored by Academic Founding of Literary Studies at Beijing International Studies University.
} 
Why does the disaster happen? It is not Blake's fault. His skill shows his shortage before the machine's challenge. The industrialized society does not need these craft workers any longer, it simply needs labors instead. This kind of suffering firmly connects Blake with the poor laboring people. In his poems, he shows great sympathy for the common persons, and great hatred to the exploiting class.

\section{Bible's influence on Blake}

Blake believes the world at his time is the fallen world. In the Revelation, when Adam and Eve are driven out of the Eden, the man's world is also fallen. But the reason is different: He think the fall of man is because of the tyrant of constricting reason, which is represented by Urizen in America, the Five Gates. He pays more attention to imagination, inspiration, and enthusiasm. That's why he speaks through Orc's throat:"I am Orc wreath'd round the accursed tree."Actually, he is tempting mankind to break the commandments of a tyrant God. He wants all the people to eat the fruits on the forbidden tree, then they will be clever and wise enough to distinguish which is good and which is bad, and use their own sense organs to feel the world. Before that, their eyes are covered by the religious doctrine. Now, let us discuss the similar points between Blake's belief and the Bible. In America, Blake borrows many useful things from Revelation.

For example: Albion's angel curses Orc: "Art thou not Orc, who serpent-form'd, stands at the gate of Enitharmon to devour her children?" Thus he looks Orc as the red dragon in Revelation, which want to devour the children of the woman clothed with the sun. England is the suzerain state. Taking America as its colony, the English government and rulers naturally consider the relation between England and America as that of mather and children. Consequently, it is intolerant for Orc to lead the revolution which will separate America from England.

In America, Blake offers the poor a happy place.

"The slave grinding at the mill run out into the field,

He look up into the heavens and laugh in the bright air

The inchained-soul shut up in darkness and sighing".

Maybe, the place is "before the throne of God" in Revelation."They will hunger no more, and thirst no more, the sun will not strike them, nor any scorching heat; we should notice, in Blake's heaven, there's no room for the rulers who can only find place in the hell. For the lamb at the center of the throne will be their shepherd, and God will wipe away every tear from their eyes, and he will guide them to springs of the water of life.

\section{Progressive writer's influence on Blake}

Blake is born in the decade of movement of democratic revolution and reform. $\mathrm{He}$ is a strong-willed protector of revolution both in words and in actions. As early as 1783, he opposes the external interference for American Revolution in "Poetic Sketch", and he takes part in the "London Revolt" which is against war and foe the democracy in the year of 1780. Later on, he keeps close connection with a radical democrat-Thomas Paine. Blake accepts his thought that it is a kind of despotic rule that there is still autocratic monarchy in England. In America, Blake critics Albion, the representative of monarchical power mercilessly. Just like Pain, Blake advocates to improve the living condition of the people, and they should have more freedom? Their friendly relationship develops quickly. Because they have common ideas. At the end of 1791, Blake saves Paine's life by insisting that Paine should not go back home after he has made a radical speech.

In the field of literature, the main influence comes from Milton. In his epic Paradise Lost, he depicts a hero with a never-give-up heart-Satan. He highly praises Satan's rebellious spirit, which encourage Satan to fight against God, the tyrant. Blake gives his comments to Milton: Milton is reserved and withdrawn when he mentions God and Angels. But he feels at home when he describes Satan. He is a member of the monsters. Blake develops Milton's thoughts because he believes that the so called "virtue" in the eyes of priests is to obey the orders of church, and "evil" is the active action coming from enthusiasm. The positions of virtue and evil, heaven and hell, angel and monster are upside-down in his poem. 
For instance, in America. Orc is not ashamed of being called serpent, the embodiment of Satan by Albion's angel, instead, he is proud of it: "I am Orc, wreathed round the accursed tree."

\section{Social background}

\section{England}

In England, the government takes the high-handed policy when George III is on the throne. It wrecks workers strike, puts the radical democrats into jail, promulgates bans to forbidden writers to expresses their progressives ideas...All of these form Blake's attitude towards the king and the government, and he uses his pen to show his hatred:"Albion sick, and Pestilence begin in streaks of red across the limbs of Albion's Guardian, the spotted plague smote Bristol's, leprosy London's spirit, sickening all their bands." The "ancient palace, archetype of mighty empires" is collapsing, that embodies the old ruling system will be destroyed by people.

In order to sack more money, the English government exploit the colonies more badly than before, When the people there want to rebel, the English government sends soldiers to suppress.

"The numerous hosts darkend the Atlantic mountains, the trumpets shook the valleys, the soldier armed with diseases of the earth, they are mummers forty millions, mastering in the eastern sky."

In England, the government takes the high-handed policy when George III is on the throne. It wrecks workers' strike, puts the radical democrats into jail, promulgates bans to fobide writers to expresses their progressives ideas...All of these form Blake's attitude towards the king and the government, and he uses his pen to show his hatred:"Albion sick, and Pestilence begin in streaks of red across the limbs of Albion's Guardian, the spotted plague smote Bristol's, leprosy London's spirit, sickening all their bands." The "ancient palace, archetype of mighty empires" is collapsing, that embodies the old ruling system will be destroyed by people.

\section{France}

It is almost impossible for us to study Blake's poem ignoring French revolution's influence, "liberty, equality and fraternity" is in everybody's mind, the heaven seems to be actualized in France, England, and all over the world.

"The morning come, the night decays", deeply moved and greatly inspired by the revolutionary ideas, Blake interprets the revolution as the initiating the millennium that had been prophesied in the apocalyptic books of the Bible-Revolution.

\section{America}

Since the American Independent War breaks out in the year of 1775, Blake keeps a close eye on America, he shows great sympathy for the people whose "faces pale and yellow, hands depress, voices wreaks......", and he takes the side of Americans who want to break the "heavy iron chain descended from Albion's cliffs."

The American armies are not well armed, but they fight very bravely, before them, the English soldiers show white feather, "they threw swords and muskets, and then their end should come". The final success brings to the justice, America has its freedom.

\section{Image of Orc}

Orc is the hero in America, on whom, Blake places all his hopes. In some degree, Orc is another Blake in this poem.

Orc's figure is always changeable: his enemies look upon him as the serpent with hissing jaws.

Orc also shows himself in the shape of fire, youth, wolf, lion, eagle, whale and serpent...

The reasons for Blake to give these images to Orc are two:

Firstly, for the sake of Romanticism, He wants to create his own mythological system. Orc is the main character who is very powerful and has vast magic powers, like the Monkey King in the Chinese meteorology "Journey to the west". Thus the poem has rich romantic elements. 
Secondly, for the sake of Realism, Blake foretells that the revolution will happen in many countries: Canada, Mexico, Peru, Span, Italy and the specific conditions in these countries are different from each other: they have different leaders, they must face with different difficulties. Therefore it is more reasonable to use different images to embody these revolutions.

Having different embodiment, Orc has different identifications.

\section{As a revolutionary}

a) Orc is the spirit of all human energy

In plate 1 and 2, we find that Orc and the daughter of Urthana fall into love with each other ,after Orc embarrasses her, she can smile and speak. Urthona, like Urizen, represents the constricting reason, which imposes limits, prohibitions and measure upon joyous human energy. The union of Orc, and the daughter of Urthona embodies the freedom of human energy, including sexual energy. From then on, people can seek their happy life freely.

Woman are victims of the feudal autocracy. They have not any right to get happiness. In plate 15, the door of marriage is open, women are set free. They are"naked and glowing with the lusts of youth", and "feel the nervous of youth renew and desires of ancient times."

The "five gates" are open, the five senses of human are active again. People are facing a rich-colored world, they can use their own senses to feel, taste and touch the world.

b) As fighter against the false church

Blake is against the traditional religion and morality. He believes that they are rotting, hypocritical and cruel to people. In fact, the church has become the tool of the ruling class.

Orc in plate 11 cried:

"Why trembles honesty and like a murderer, why seeks he refuge from the frowns of his immortal station."

Then Orc exposes the duplicity and hypocrisy of the church.

"Pity is become a trade, and generosity a science. The angel lusts of tears, and fans himself with sighs."

Though the angel preaches abstinence and wraps himself in fat of lambs, actually he is an indeed villain and lechery. Compared with him, a harlot is purer, she has virginity.

"That stony law I stamp to dust, and scatter religion abroad. To the four winds as a torn book, and none shall gather the leaves."

By saying this, Blake abandons old religious beliefs.

In plate 15, we see a very hideous fellow: the bard of Albion. He has "a cowl of flesh on his head, and is covered by scales on his back and ribs", Here, Blake refers to Edmund Burke who writes a pamphlet in 1790. He attacks French Revolution and plays up the old ruling system.

\section{As the leader}

A successful revolution needs a wise leader. In American Independent War, people choose Washington, and in America Blake chooses Orc. Orc is full of vigor. He is born in human fire, and he can renew himself like serpent. Just like fire, he spreads revolutionary ideas all over the world, like serpent, which tempts Eve to eat the forbidden fruit, Orc teaches people to know the evil deeds made by government and church, then call people to raise up and to rebel.

In addition, Orc avoids the shortages of fire-aimlessness. He knows strategies very well: without the response of people, the revolution can never be successful. So the first thing he does is to unveil the marks of government and church, letting people know their true colors.

"The citizens of New York close their book and lock their chests. The mariners of Boston drop their anchors and unlade, ......"

Then he gets support from the 13 angels, who follow him: they "rent off their robes to the hungry wind and threw their golden scepters", to show their resolution. Leading the just army, Orc reach success.

\section{As a prophet}

Orc uses his ability of foretelling the bright future to encourage people to fight for it. 
"The sun has left his blackness, has found a fresher morning and the fair moon rejoices in the clear and cloudless night."

For empire is no more and now the lion and wolf shall cease."

Orc's incarnations: serpent in Canada, eagle in Mexicoand so on, indicates the revolution will outbreak in the all countries very soon, and the old world will be replace by a new one.

\section{Conclusion}

In America, Blake opposes aggression and colonism, refutes oppression of church, attacks exploitation, heasks for liberation of human's energy, praise "liberty, equality and fraternity". Orc is Blake's spokesman.

Albion and Urizen represent the autocrat, traditional church, constricting reason.

\section{References}

[1] Annette: The Great Tradition of British Poems, (Shanghai Translation Publishing House, China 1998)

[2] Jiang mengyin: British History, (Social Science Press, China 1988)

[3] Yuan kejia: William Blake's Poems, (Chinese Social Science Press, China 1985)

[4] Zhang deming: On the Myth and Archetype in William Blake's Poems, in Foreign Literature Review, (Jan, 1990), p.13-p.20 